\title{
A NEW TRITERPENE GLYCOSIDE FROM THE SEA CUCUMBER HOLOTHURIA SCABRA COLLECTED IN VIETNAM
}

\author{
Nguyen Van Thanh, Nguyen Hai Dang, Phan Van Kiem, Nguyen Xuan Cuong, \\ Hoang Thanh Huong, and Chau Van Minh*
}

Institute of Natural Products Chemistry, Vietnamese Academy of Science and Technology, 18 Hoang Quoc Viet, Caugiay, Hanoi, Vietnam

Received 12 May 2006

\begin{abstract}
Bioassay guided fractionation led to the isolation of a new triterpene glycoside, holothurinogenin B (1) along with three known compounds, holothurin B (2), holothurin A (3), and holothurin $\mathrm{A}_{2}$ (4), from the methanol extract of the Vietnamese sea cucumber Holothuria scabra. Their structures were deduced from the spectral analysis (1D-NMR, 2D-NMR, MS) and chemical evidences.
\end{abstract}

Keywords: Triterpene glycosides, Sea cucumber, Holothuria scabra, Holothurinogenin B.

\section{INTRODUCTION}

Sea cucumbers belong to the class Holothurioidea which widely distributed in Atlantic and Pacific Oceans. They have been used in Vietnamese traditional medicine for long time as tonics and delicacies [1]. Pacific islanders used the holothurian body tissues as a toxin to kill fishes. To date, dozens of triterpene glycosides of holostane type have been identified from the holothurians [2,3]. They expressed a broad spectrum of antifungal, antibacterial and cytotoxic activity $[4,5]$. As a part of our on going study on bioactive substances from marine invertebrates, we have isolated several triterpene glycosides from the polar fractions of methanol extracts of the sea cucumber Holothuria scabra collected in Vietnam whose structures were elucidated by spectral data $\left({ }^{1} \mathrm{H}-\mathrm{NMR},{ }^{13} \mathrm{C}-\mathrm{NMR}\right.$, DEPT, 2D-NMR and ESI MS).

\section{RESULTS AND DISCUSSION}

Compound 1 was obtained as amorphous powders. The molecular formula was established as $\mathrm{C}_{41} \mathrm{H}_{62} \mathrm{O}_{13}$ from the $[\mathrm{M}+\mathrm{H}]^{+}$ion at $\mathrm{m} / \mathrm{z} 762.7,[\mathrm{M}+\mathrm{Na}]^{+}$ion at $\mathrm{m} / \mathrm{z} 785.3$ in the positive ion mode ESI MS and from the $[\mathrm{M}-\mathrm{H}]^{-}$ion at $\mathrm{m} / \mathrm{z} 761.3$ in the negative ion mode. The ${ }^{13} \mathrm{C}$-NMR spectrum of 1 revealed that the aglycon part was similar to 22,25-oxidoholothurinogenin, an artificial genin from Holothuria leucospilota which possesses two olefinic double bonds and a lactone carbonyl group in the holostane nucleus [6, 7]. The ${ }^{1} \mathrm{H}-\mathrm{NMR},{ }^{13} \mathrm{C}-\mathrm{NMR}$ and DEPT spectra displayed resonances due to the presence of seven tertiary methyl groups, two olefinic bonds at $\mathrm{C}-7\left(\delta_{\mathrm{H}} 5.55, \delta_{\mathrm{C}} 121.0 / \mathrm{C}-8\left(\delta_{\mathrm{C}} 142.7\right)\right.$ and $\mathrm{C}-9\left(\delta_{\mathrm{C}} 148.8\right) / \mathrm{C}-11\left(\delta_{\mathrm{H}} 5.30, \delta_{\mathrm{C}} 113.2\right)$ and

\footnotetext{
* Corresponding author e-mail: cvminh@fpt.vn
} 
$\mathrm{C}-11\left(\delta_{\mathrm{H}} 5.30, \delta_{\mathrm{C}} 113.2,148.8\right)$, and one lactone carbonyl group $\left(\delta_{\mathrm{C}} 178.3\right)$. The correlations of $\mathrm{H}-7$ to $\mathrm{C}-6, \mathrm{H}-11$ to $\mathrm{C}-8, \mathrm{C}-10, \mathrm{C} 12$ and $\mathrm{C}-13$ was obtained in the HMBC, these confirmed the position of two double bonds in the holostane skeleton at C-7/C-8 and C-9/C-11. The ${ }^{13} \mathrm{C}-\mathrm{NMR}$ spectrum had a signal characteristic for the presence of a hydroxyl group at $\mathrm{C}-17\left(\delta_{\mathrm{C}} 86.9\right)$. The side chain in aglycon moiety of $\mathbf{1}$ was shown to be identical to that of holothurin B by comparison of the NMR spectra of their corresponding side part [8]. The remaining part of the aglycon was confirmed by ${ }^{1} \mathrm{H}-\mathrm{NMR},{ }^{13} \mathrm{C}-\mathrm{NMR}$, HSQC, and HMBC spectra (Table 1) and was identical to the artificial compound 22,25-oxidoholothurinogenin.

Table 1: ${ }^{13} \mathrm{C}$ and ${ }^{1} \mathrm{H}$-NMR chemical shifts and selected HMBC correlations of holothurinogenin $B$ (1) aglycon moiety

\begin{tabular}{|c|c|c|c|}
\hline Atom & $\delta_{\mathrm{C}}^{\mathrm{a}, \mathrm{b}}$ & $\delta_{\mathrm{H}}^{\mathrm{a}, \mathrm{c}}(\mathrm{J}, \mathrm{Hz})$ & HMBC \\
\hline 1 & 36.4 & $2.8(2 \mathrm{H}, \mathrm{m})$ & $\mathrm{C}-5$ \\
\hline 2 & 28.9 & $2.06(2 \mathrm{H}, \mathrm{m})$ & \\
\hline 3 & 90.6 & $3.15(1 \mathrm{H}, \mathrm{m})$ & C-1 Xyl; C-28 \\
\hline 4 & 40.8 & & \\
\hline 5 & 51.3 & $1.15(1 \mathrm{H}, \mathrm{m})$ & \\
\hline 6 & 23.9 & $2.13(2 \mathrm{H}, \mathrm{dd}, 4.5 ; 6.5)$ & $\mathrm{C}-7 ; \mathrm{C}-8$ \\
\hline 7 & 121.0 & $5.55(2 \mathrm{H}, \mathrm{m})$ & $\mathrm{C}-6$ \\
\hline 8 & 142.7 & & \\
\hline 9 & 148.8 & & \\
\hline 10 & 40.3 & & \\
\hline 11 & 113.2 & $5.30(1 \mathrm{H}, \mathrm{m})$ & $\mathrm{C}-8 ; \mathrm{C}-10 ; \mathrm{C}-12 ; \mathrm{C}-13$ \\
\hline 12 & 29.7 & $2.25-2.85(2 \mathrm{H}, \mathrm{m})$ & C-9; C-11; C-13; C-14; C-18 \\
\hline 13 & 58.9 & & \\
\hline 14 & 49.6 & & \\
\hline 15 & 27.7 & $1.82(2 \mathrm{H}, \mathrm{m})$ & C-14; C-30; C-13; C-17 \\
\hline 16 & 34.8 & $1.35-1.85(2 \mathrm{H}, \mathrm{m})$ & $\mathrm{C}-17$ \\
\hline 17 & 86.9 & & \\
\hline 18 & 178.3 & & \\
\hline 19 & 23.1 & $1.12(3 \mathrm{H}, \mathrm{s})$ & $C-5, C-9, C-10$ \\
\hline 20 & 87.1 & & \\
\hline 21 & 18.2 & $1.37(3 \mathrm{H}, \mathrm{s})$ & $\mathrm{C}-20, \mathrm{C}-22$ \\
\hline 22 & 81.8 & $4.21(1 \mathrm{H}, \mathrm{t}, 7.0)$ & $\mathrm{C}-21 ; \mathrm{C}-20$ \\
\hline 23 & 28.5 & $2.05(2 \mathrm{H}, \mathrm{m})$ & $\mathrm{C}-24 ; \mathrm{C}-25$ \\
\hline 24 & 39.3 & $1.78-1.82(2 \mathrm{H}, \mathrm{m})$ & $\mathrm{C}-23$ \\
\hline 25 & 82.9 & & \\
\hline 26 & 28.9 & $1.31(3 \mathrm{H}, \mathrm{s})$ & $\mathrm{C}-24, \mathrm{C}-25, \mathrm{C}-27$ \\
\hline 27 & 27.7 & $1.27(3 \mathrm{H}, \mathrm{s})$ & $\mathrm{C}-24, \mathrm{C}-25, \mathrm{C}-26$ \\
\hline 28 & 17.2 & $0.98(3 \mathrm{H}, \mathrm{s})$ & C-3, C-4, C-5, C-29 \\
\hline 29 & 28.6 & $1.11(3 \mathrm{H}, \mathrm{s})$ & C-3, C-4, C-5, C-28 \\
\hline 30 & 25.4 & $1.22(3 \mathrm{H}, \mathrm{s})$ & $\mathrm{C}-8, \mathrm{C}-14, \mathrm{C}-13$ \\
\hline
\end{tabular}

${ }^{\mathrm{a}} \mathrm{In} \mathrm{CD}_{3} \mathrm{OD}$, ${ }^{\mathrm{b}}$ recorded at $125 \mathrm{MHz},{ }^{\mathrm{c}}$ recorded at $500 \mathrm{MHz}$. 
Compound 1 differs from the artificial genin by the presence of an oligosaccharide chain composed of two sugar units. The ${ }^{1} \mathrm{H}-\mathrm{NMR}$ and ${ }^{13} \mathrm{C}-\mathrm{NMR}$ spectra of $\mathbf{1}$ were similar to those of holothurin B which has carbonhydrate chain (a $D$-xylose attached to a $D$-quinovose) at C-3 ( $\delta_{\mathrm{C}}$ 90.6) of the aglycon. The ${ }^{1} \mathrm{H}-\mathrm{NMR}$ spectrum of $\mathbf{1}$ exhibited two anomeric proton signals at $\delta_{\mathrm{H}}$ $4.42(\mathrm{~d}, J=7.0 \mathrm{~Hz}$, xylose $)$ and $\delta_{\mathrm{H}} 4.55(\mathrm{~d}, J=7.5 \mathrm{~Hz}$, quinovose $)$ and a doublet at $\delta_{\mathrm{H}} 1.28(J=$ $6.0 \mathrm{~Hz}$ ) confirmed the position of a methyl group of the quinovose residue. The upfield shift at C-4 signal $\left(\delta_{\mathrm{C}} 71.1\right)$ demonstrated the absence of sulfate at C-4 of the xylose unit. The structure of sugar moiety was deduced by using ${ }^{1} \mathrm{H}-\mathrm{NMR},{ }^{13} \mathrm{C}-\mathrm{NMR}$, HSQC and HMBC spectra (Table 2 ). Based on the spectroscopic evidence and in comparison with published literature $[2,8]$, compound 1 was elucidated to be $3 \beta-O-[\beta-D$-quinovopyranosyl- $(1 \rightarrow 2)-\beta-D$-xylopyranosyl]22,25-epoxyholosta-7,9(11)-diene-17-ol, which we named as holothurinogenin B. To our best knowledge, this compound was isolated for the first time from the nature.

The ${ }^{1} \mathrm{H}$-NMR and ${ }^{13} \mathrm{C}-\mathrm{NMR}$ spectra of compounds $\mathbf{2}, \mathbf{3}$, and $\mathbf{4}$ showed the similar signals from $\mathrm{C}-1 \rightarrow \mathrm{C}-18$ coincident with those of holothurin B (Fig. 2) which possesses one olefinic double bond, two hydroxyl groups at $\mathrm{C}-12$ and $\mathrm{C}-17$ and one lactone carbonyl group. The spectral data of 2 was identical to that of holothurin B, a holostane skeleton with 22,25-epoxy side chain and a glycoside moiety composed of two sugar units (Quinovose $(1 \rightarrow 2)$ Xylose). Thus 2 was identified to be $3 \beta-O-[\beta-D$-quinovopyranosyl- $(1 \rightarrow 2)-4-O$-sodium sulfate- $\beta$ - $D$-xylopyranosyl]22,25-epoxyholosta-9-en-12 $\alpha$-17-diol, which was well known as holothurin B [7, 8]. Similarily, the spectral data of 3 was compared to that of holothurin $A$ and found to match $[6,9]$.

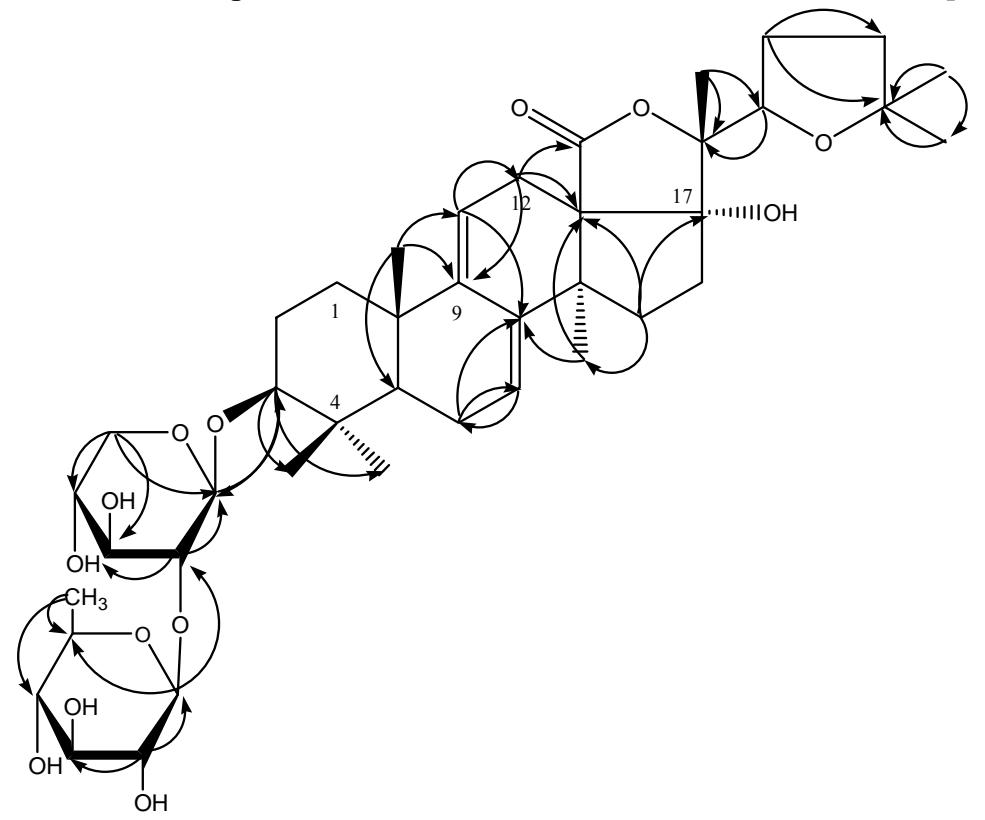

Fig. 1: Selected HMBC correlations of holothurinogenin B (1)

The spectroscopic data of the aglycon and sugar moiety of $\mathbf{4}$ was coincident to that of $\mathbf{3}$ except for the data of the side chain. This suggested that $\mathbf{4}$ has the same holostane skeleton and tetrasaccharide chain composed of four sugar units with 3 but difference of the side chain subtitute. By inspecting the ${ }^{1} \mathrm{H}-\mathrm{NMR},{ }^{13} \mathrm{C}-\mathrm{NMR}$, DEPT and 2D-NMR, the structure of $\mathbf{4}$ was clarified. The NMR spectrum of the side chain in the aglycon moiety showed resonances due to two methyl groups at $\delta_{\mathrm{H}} 0.86(6 \mathrm{H}, \mathrm{d}, 6.5 \mathrm{~Hz}, \mathrm{H}-26,27)$ and $\delta_{\mathrm{C}} 2.4(\mathrm{C}-26,27)$. The HMBC spectrum exhibited the correlations of H-26 to C-24, C-25, C-27 and H-21 to C-22, C-23 which confirmed the iso-hexane side chain. By the above evidence and comparison with previous data, compound 4 was determined as Holothurin $\mathrm{A}_{2}(3 \beta, 12 \alpha, 17 \alpha$-trihydroxyhost-9(11)-ene-3-O-[(3$O$-methyl)- $\beta$ - $D$-glucopyranosyl-(1-3)- $\beta$ - $D$-glucopyranosyl-(1-4)- $\beta$ - $D$-quinovopyranosyl-(1-2)- 
(4-sulfo)- $\beta$ - $D$-xylopyranoside] sodium salt). This compound was first time reported in this species [10].

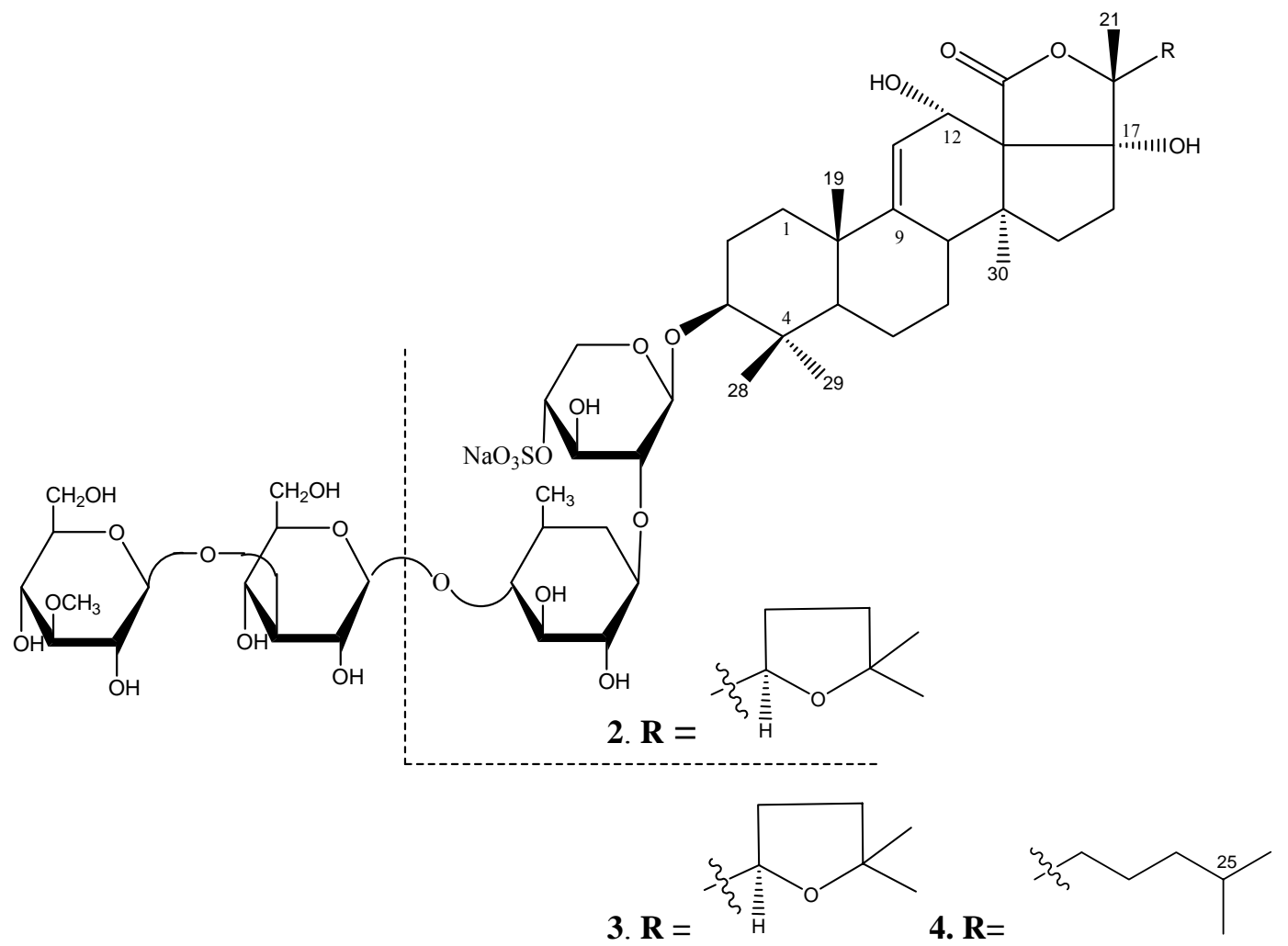

Fig. 2: Structures of 2, 3, and 4

Table 2: ${ }^{13} \mathrm{C}$ and ${ }^{1} \mathrm{H}$-NMR chemical shifts and selected HMBC correlations of holothurinogenin B (1) sugar moiety

\begin{tabular}{lccl}
\hline Position & $\delta_{\mathrm{C}}^{\mathrm{a}, \mathrm{b}}$ & $\delta_{\mathrm{H}}^{\mathrm{a}, \mathrm{c}}$ & \multicolumn{1}{c}{$\mathrm{HMBC}$} \\
\hline Xyl $(1 \rightarrow \mathrm{C} 3)$ & & & \\
1 & 106.0 & $4.42(1 \mathrm{H}, \mathrm{d}, J=7.0 \mathrm{~Hz})$ & $\mathrm{C}-3$ \\
2 & 83.1 & $3.49(1 \mathrm{H}, \mathrm{m})$ & $\mathrm{C}-1, \mathrm{C}-3 \mathrm{Xyl}$ \\
3 & 77.8 & $3.53(1 \mathrm{H}, \mathrm{m})$ & $\mathrm{C}-2, \mathrm{C}-4 \mathrm{Xyl}$ \\
4 & 71.1 & $3.54(1 \mathrm{H}, \mathrm{m})$ & $\mathrm{C}-3 \mathrm{Xyl}$ \\
5 & 66.4 & $3.23-3.87(2 \mathrm{H}, \mathrm{m})$ & $\mathrm{C}-1, \mathrm{C}-3, \mathrm{C}-4$ Xyl \\
Qui $(1 \rightarrow 2 \mathrm{Xyl})$ & & & \\
1 & 105.6 & $4.55(1 \mathrm{H}, \mathrm{d}, J=7.5 \mathrm{~Hz})$ & $\mathrm{C}-2$ Xyl, C-5 Qui \\
2 & 76.9 & $3.26(1 \mathrm{H}, \mathrm{m})$ & $\mathrm{C}-1, \mathrm{C}-3$ Qui \\
3 & 77.5 & $3.34(1 \mathrm{H}, \mathrm{m})$ & $\mathrm{C}-1, \mathrm{C}-4$ Qui \\
4 & 77.0 & $3.00(1 \mathrm{H}, \mathrm{m})$ & $\mathrm{C}-3, \mathrm{C}-5, \mathrm{C}-6$ Qui \\
5 & 73.7 & $3.33(1 \mathrm{H}, \mathrm{m})$ & \\
$6\left(\mathrm{CH}_{3}\right)$ & 18.1 & $1.28(3 \mathrm{H}, \mathrm{d}, 1.66)$ & $\mathrm{C}-4, \mathrm{C}-5$ Qui \\
\hline
\end{tabular}

${ }^{\mathrm{a}}$ In $\mathrm{CD}_{3} \mathrm{OD}$, ${ }^{\mathrm{b}}$ recorded at $125 \mathrm{MHz},{ }^{\mathrm{c}}$ recorded at $500 \mathrm{MHz}$. 
The isolation and determination of a new compound holothurinogenin $\mathrm{B}$ together with holothurin $\mathrm{A}, \mathrm{B}, \mathrm{A}_{2}$ are precious for investigating the chemical diversity of marine organisms. Holothurin A and B are the major components of Holothuria scabra and many other holothurins [11]. This class of compound shows typical cytotoxic activity which suggested for the development of anticancer agents in the years to come.

\section{EXPERIMENTAL SECTION}

\subsection{General experimental procedures}

The ${ }^{1} \mathrm{H}-\mathrm{NMR}(500 \mathrm{MHz})$ and ${ }^{13} \mathrm{C}-\mathrm{NMR}(125 \mathrm{MHz})$ spectra were recorded on a Bruker AM500 FT-NMR spectrometer. Chemical shifts are referenced to $\delta$ using tetramethylsilan (TMS) as an internal standard. The Electron Spray Ionization (ESI) mass spectrum was obtained using a AGILENT 1100 LC-MSD Trap spectrometer. Column chromatography (CC) was performed on silicagel 230 - 400 mesh $(0,040-0,063 \mathrm{~mm}$, Merck) or YMC RP-18 resins $(30-50 \mu \mathrm{m}$, FuJisilisa Chemical Ltd., Merck). Thin layer chromatography (TLC) was performed on DCAlufolien $60 \mathrm{~F}_{254}$ (Merck 1,05715) or $\mathrm{RP}_{18} \mathrm{~F}_{254 \mathrm{~s}}$ (Merck) plates.

\subsection{Animal materials}

The specimens of Holothuria scabra were collected at a deep of 3 - $30 \mathrm{~m}$ in Catba, Haiphong province, North of Vietnam in Feb, 2006 and deep frozened until used. The sea cucumber Holothuria scabra was identified by Dr. Do Cong Thung, Institute of Marine Resources and Environment, Vietnamese Academy of Science and Technology, Vietnam. A voucher of specimen was deposited at Institute of Natural Products Chemistry, Vietnamese Academy of Science and Technology, Hanoi, Vietnam.

\subsection{Extraction and isolation}

Dried specimens of the sea cucumber were extracted three times with $\mathrm{MeOH}$ (7 days each time) and then concentrated under low pressure to obtain $150 \mathrm{~g} \mathrm{MeOH}$ extract. The $\mathrm{MeOH}$ extract were suspended in water and partition with hexane, chloroform and $\mathrm{n}$ - butanol. All fractions were tested with cytotoxic activity with two cancer cell lines KB (Human epidermoid carcinoma) and Hep-2 (Human hepatocellular carcinoma) in an in vitro assay system. The $\mathrm{CHCl}_{3}$ and $\mathrm{BuOH}$ fractions showed considerable activity and were selected for futher isolation of bioactive components. The $\mathrm{BuOH}$ fraction was chromatographed on silicagel column eluting with $\mathrm{CHCl}_{3}-\mathrm{MeOH}$ gradient (from 10:1 to 1:1) to give fraction $\mathrm{B} 1, \mathrm{~B} 2$, and B3. Fraction B2 yeilded $20 \mathrm{mg}$ of pure holothurinogenin $\mathrm{B}$ and $100 \mathrm{mg}$ of holothurin $\mathrm{B}$ by using reversed phase YMC column with Acetone $-\mathrm{H}_{2} \mathrm{O}$ (3:1). Fration B3 was chromatographed using $\mathrm{CHCl}_{3}-$ $\mathrm{MeOH}-\mathrm{H}_{2} \mathrm{O}(20: 10: 1)$ to afford pure holothurin $\mathrm{A}(70 \mathrm{mg})$ and holothurin $\mathrm{A}_{2}(6 \mathrm{mg})$.

\subsection{Holothurin B (2)}

White powder; mp. $223-225^{\circ} \mathrm{C}$; FAB MS (positive ion mode) $\mathrm{m} / \mathrm{z} 905.2[\mathrm{M}+\mathrm{Na}]^{+}$; ${ }^{1} \mathrm{H}-\mathrm{NMR}$ (500 MHz, DMSO) $\delta$ (ppm): 0.89 (3H, s, H-28), 1.03 (3H, s, H-27), $1.12(3 \mathrm{H}, \mathrm{s}, \mathrm{H}-26), 1.28$ $(3 \mathrm{H}, \mathrm{s}, \mathrm{H}-29), 1.39$ (3H, s, H-19), 1.50 (3H, s, H-30), 1.65 (3H, s, H-21), 1.65 (3H, d, $6.0 \mathrm{~Hz}, \mathrm{H}-$ 6 Qui), $3.16(1 \mathrm{H}, \mathrm{dd}, 10.0,3.0 \mathrm{~Hz}, \mathrm{H}-3), 3.45(1 \mathrm{H}, \mathrm{m}, \mathrm{H}-8), 4.90(1 \mathrm{H}, \mathrm{d}, 7.0 \mathrm{~Hz}, 1-\mathrm{Xyl}), 5.25$ $(1 \mathrm{H}, \mathrm{d}, 7.8 \mathrm{~Hz}, 1-\mathrm{Qui}), 5.31(1 \mathrm{H}, \mathrm{d}, 5.0 \mathrm{~Hz}, \mathrm{H}-11) ;{ }^{13} \mathrm{C}-\mathrm{NMR}(125 \mathrm{MHz}) \delta(\mathrm{ppm}): 35.2(\mathrm{C}-1)$, 27.1 (C-2), 88.7 (C-3), 40.0 (C-4), 52.8 (C-5), 20.2 (C-6), 28.2 (C-7). 40.9 (C-8), 153.5 (C-9), 39.8 (C-10), 115.4 (C-11), 71.1 (C-12), 58.3 (C-13), 45.7 (C-14), 27.1 (C-15), 38.6 (C-16), 89.3 (C-17), 174.4 (C-18), 18.8 (C-19), 86.9 (C-20), 22.5 (C-21), 80.3 (C-22), 28.7 (C-23), 36.5 (C24), 81.6 (C-25), 28.3 (C-26), 28.2 (C-27), 21.2 (C-28), 27.9 (C-29), 16.7 (C-30) Xyl (1) 105.1, 
(2) 82.4, (3) 76.7, (4) 75.2, (5) 63.9 Qui (1) 105.1, (2) 75.6, (3) 76.6, (4) 76.2, (5) 72.8, (6) 18.3.

\subsection{Holothurin A (3)}

White powder; mp. $228-230^{\circ} \mathrm{C}$; ${ }^{1} \mathrm{H}-\mathrm{NMR}(500 \mathrm{MHz}, \mathrm{DMSO}) \delta(\mathrm{ppm}): 0.89(6 \mathrm{H}, \mathrm{s}, \mathrm{H}-27,28)$, $1.02(3 \mathrm{H}, \mathrm{s}, \mathrm{H}-26), 1.22(3 \mathrm{H}, \mathrm{s}, \mathrm{H}-29), 1.40(3 \mathrm{H}, \mathrm{s}, \mathrm{H}-19), 1.50(3 \mathrm{H}, \mathrm{s}, \mathrm{H}-30), 1.52(3 \mathrm{H}, \mathrm{s}, \mathrm{H}-$ 21), $1.72(3 \mathrm{H}, \mathrm{d}, 6.0 \mathrm{~Hz}, \mathrm{H} 6 \mathrm{Qui}), 3.15(1 \mathrm{H}, \mathrm{dd}, 10.0,3.0 \mathrm{~Hz}, \mathrm{H}-3), 3.40(1 \mathrm{H}, \mathrm{m}, \mathrm{H}-8), 3.58$ $(3 \mathrm{H}, \mathrm{s}, \mathrm{OMe}), 4.35(1 \mathrm{H}, \mathrm{d}, 7.0 \mathrm{~Hz}, 1-\mathrm{Glc}), 4.36(1 \mathrm{H}, \mathrm{d}, 7.0 \mathrm{~Hz}, 1-\mathrm{Glc}(\mathrm{OMe})), 4.65(1 \mathrm{H}, \mathrm{d}, 7.0$ $\mathrm{Hz}, 1-\mathrm{Xyl}), 5.15(1 \mathrm{H}, \mathrm{d}, 7.0 \mathrm{~Hz}, \mathrm{H}-11), 1-\mathrm{Qui}), 5.35(1 \mathrm{H}, \mathrm{d}, 5.0 \mathrm{~Hz}, \mathrm{H}-11) ;{ }^{13} \mathrm{C}-\mathrm{NMR}(125$ MHz) $\delta(\mathrm{ppm}): 34.8$ (C-1), 27.2 (C-2), 87.9 (C-3), 40.2 (C-4), 51.9 (C-5), 21.3 (C-6), 28.2 (C7), 39.5 (C-8), 152.7 (C-9), 39.5 (C-10), 114.5 (C-11), 71.8 (C-12), 59.9 (C-13), 46.0 (C-14), 27.4 (C-15), 38.8 (C-16), 88.2 (C-17), 173.7 (C-18), 19.3 (C-19), 86.4 (C-20), 22.5 (C-21), 81.5 (C-22), 28.9 (C-23), 35.8 (C-24), 79.1 (C-25), 27.4 (C-26), 27.4 (C-27), 21.4 (C-28), 27.4 (C29), 16.2 (C-30). Xyl (1) 103.9, (2) 81.5, (3) 77.1, (4) 74.3, (5) 63.0 Qui (1) 103.8, (2) 75.5, (3) 76.1 , (4) 86.7, (5) 72.2, (6) 17.3 Glc (1) 103.6, (2) 75.1, (3) 86.0, (4) 70.8, (5) 77.3, (6) 60.9 Glc (OMe) (1) 104.3, (2) 74.9, (3) 87.5, (4) 69.6, (5) 77.6, (6) 62.1, $\left(\mathrm{OCH}_{3}\right)$ 59.9.

\subsection{Holothurin $A_{2}(4)$}

White powder; ${ }^{1} \mathrm{H}-\mathrm{NMR}(500 \mathrm{MHz}, \mathrm{DMSO}) \delta(\mathrm{ppm}): 0.81(3 \mathrm{H}, \mathrm{s}, \mathrm{H}-28), 0.86(6 \mathrm{H}, \mathrm{d}, 6.5 \mathrm{~Hz}$, H-26, 27), 1.01 (3H, s, H-29), 1.04 (3H, s, H-19), 1.20 (3H, s, H-30), 1.42 (3H, s, H-21), 4.43 $(1 \mathrm{H}, \mathrm{d}, 4.0 \mathrm{~Hz}, \mathrm{H}-12), 5.25(1 \mathrm{H}, \mathrm{d}, 4.0 \mathrm{~Hz}, \mathrm{H}-11) .{ }^{13} \mathrm{C}-\mathrm{NMR}(125 \mathrm{MHz}) \delta(\mathrm{ppm}): 35.8(\mathrm{C}-1)$, 26.1 (C-2), 87.6 (C-3), 39.0 (C-4), 51.9 (C-5), 20.3 (C-6), 27.4 (C-7), 40.0 (C-8), 152.6 (C-9), 39.8 (C-10), 114.5 (C-11), 70.1 (C-12), 57.4 (C-13), 45.3 (C-14), 38.8 (C-15), 34.7 (C-16), 87.1 (C-17), 173.6 (C-18), 21.9 (C-19), 86.2 (C-20), 22.5 (C-21), 35.8 (C-22), 21.3 (C-23), 38.9 (C24), 27.2 (C-25), 22.4 (C-26), 22.4 (C-27), 16.2 (C-28), 27.4 (C-29), 19.2 (C-30) Xyl (1) 103.6, (2) 81.4 , (3) 74.8 , (4) 74.2 , (5) 63.0 Qui (1) 103.8 , (2) 74.5 , (3) 74.2 , (4) 85.9, (5) 70.0 , (6) 17.3 Glc (1) 104.6, (2) 72.1, (3) 87.9, (4) 68.4, (5) 76.7, (6) 60.7 Glc (OMe) (1) 103.9, (2) 73.5, (3) 86.2, (4) 69.3, (5) 76.9, (6) 60.9, $\left(\mathrm{OCH}_{3}\right) 59.8$.

\section{REFERENCES}

1. Bich, D.H., Chung, D.Q., Chuong, B.X., Dong, N.T., Dam, D.T., Hien, P.V., Lo, V.N., Mai, P.D., Man, P.K., Nhu, D.T., Tap, N., and Toan, T. (2006), Medicinal Animals and Plants in Vietnam. Science and Technology Publishing House, vol. 1, pp. 1227-1228.

2. Zhang, S.Y., Yi, Y.H., and Tang, H.F. (2006), Bioactive triterpene glycosides from the sea cucumber Holothuria fuscocinerea. J. Nat. Prod., vol. 69, pp. 1492-1495.

3. Zou, Z.R., Yi, Y.H., Wu, H.M., Wu, J.H., Liaw, C.C., and Lee, K.H. (2003), Intercedensides A-C, three new cytotoxic triterpene glycosides from the sea cucumber Mensamaria intercedens lampert. J. Nat. Prod., vol. 66, pp. 1055-1060.

4. Chludil, H.D., Muniain, C.C., Seldes, A.M., and Maier, M.S. (2002), Cytotoxic and antifungal triterpene glycosides from the patagonian sea cucumber Hemoiedema spectabilis. J. Nat. Prod., vol. 65, pp. 860-865.

5. Ana Maria de Moncerrat Iniguez-Martinez, Graciela Guerra-Rivas, Tirso Rios, and Leovigildo Quijano (2005), Triterpenoid oligoglycosides from the sea cucumber Stichopus parvimensis. J. Nat. Prod. vol. 68, pp. 1669-1673.

6. Kitagawa, I., Nishino, T., Kobayashi, M., Matsuno, T., Akutsu, H., and Kyogoku, Y. (1981), Marine Natural Products; Bioactive triterpene-oligoglycosides from the sea cucumber Holothuria leucospilota brandt (1). Structure of holothurin B. Chem. Pharm. Bull., vol. 29(7), pp. 1942-1950. 
7. Kitagawa, I., Nishino, T., Kobayashi, H., and Kyogoku, Y. (1981), Marine Natural Products; Bioactive triterpene-oligoglycosides from the sea cucumber Holothuria leucospilota bandt (2). Structure of Holothurin A. Chem. Pharm. Bull., vol. 29(7), pp. 19511956.

8. Silchenko, A.S., Stonik, V.A., Avilov, S.A., Kalinin, V.I., Kalinovsky, A.I., Zaharenko, A.M., Smirnov, A.V., Mollo, E., and Cimino, G. (2005), Holothurins B2, B3, and B4, new triterpene glycosides from mediterranean sea cucumbers of the genus Holothuria. J. Nat. Prod., vol. 68, pp. 564-567.

9. Minh, C.V., Kiem, P.V., Huong, L.M., Long, P.Q., and Kim, Y.H. (2005), Triterpeneglycosides of lanostane type with cytotoxic activity from Holothuria martensii. Vietnamese Journal of Chemistry, vol. 43(6), pp. 768-772.

10. Ahmad, V.U. and Basha, A. (2000), Spectroscopic Data of Saponins - Triterpenoid Glycosides, CRC Press, pp. 372-373.

11. Avilov, S.A., Kalinin, V.I., and Smirnov, A.V. (2004), Use of triterpene glycosides for resolving taxonomic problems in the sea cucumber genus Cucumaria (Holothurioidea, Echinodermata). Biochemical Systematics and Ecology, vol. 32, pp. 715-733. 